\title{
Modeling of the Total Alkalinity and the Total Inorganic Carbon in the Mediterranean Sea
}

\author{
Abed El Rahman Hassoun ${ }^{1,2,3, ~ *}$, Elissar Gemayel 1, 2, 3, Evangelia Krasakopoulou ${ }^{4,5}$, \\ Catherine Goyet $^{2,3}$, Marie Abboud-Abi Saab ${ }^{1}$, Patrizia Ziveri ${ }^{6}$, Franck Touratier ${ }^{2,3}$, \\ Véronique Guglielmi ${ }^{2,3}$, Cédric Falco ${ }^{2,3}$ \\ ${ }^{1}$ National Council for Scientific Research, National Center for Marine Sciences, Batroun, Lebanon \\ ${ }^{2}$ IMAGES_ESPACE-DEV, Université de Perpignan Via Domitia, Perpignan, France \\ ${ }^{3}$ ESPACE-DEV, UG UA UR UM IRD, Maison de la télédétection, 500 rue Jean-François Breton, Montpellier, France \\ ${ }^{4}$ Institute of Oceanography, Hellenic Centre for Marine Research, Anavyssos, Greece \\ ${ }^{5}$ University of the Aegean, Department of Marine Sciences, University Hill, Mytilene, Greece \\ ${ }^{6}$ ICREA - Institute of Environmental Science and Technology (ICTA), Universitat Autònoma de Barcelona, Ed. Z, ICTA-ICP, Carrer de les \\ columnes, E- 08193 Bellaterra, Barcelona, Spain
}

\section{Email address:}

abedhassoun@gmail.com (A. E. R. Hassoun), elissargemayel@hotmail.com (E. Gemayel), ekras@marine.aegean.gr (E. Krasakopoulou), cgoyet@univ-perp.fr (C. Goyet), mabisaab@cnrs.edu.lb (M. Abboud-Abi Saab), patrizia.ziveri@uab.cat (P. Ziveri), touratier@univ-perp.fr (F. Touratier), veronique.guglielmi@univ-perp.fr (V. Guglielmi), cedric.falco@univ-perp.fr (C. Falco)

\section{To cite this article:}

Abed El Rahman Hassoun, Elissar Gemayel, Evangelia Krasakopoulou, Catherine Goyet, Marie Abboud-Abi Saab, Patrizia Ziveri, Franck Touratier, Véronique Guglielmi, Cédric Falco. Modeling of the Total Alkalinity and the Total Inorganic Carbon in the Mediterranean Sea. Journal of Water Resources and Ocean Science. Vol. 4, No. 1, 2015, pp. 24-32. doi: 10.11648/j.wros.20150401.14

\begin{abstract}
Measurements of the $\mathrm{CO}_{2}$ system parameters in the Mediterranean Sea are relatively scarce and not representative for all its sub-basins. High quality data collected on May 2013 during the 2013 MedSeA cruise covering the whole basin were used to provide for the first time linear relationships estimating the total alkalinity $\left(\mathrm{A}_{\mathrm{T}}\right)$ and the total dissolved inorganic carbon $\left(C_{\mathrm{T}}\right)$ from salinity in each Mediterranean basin and sub-basin at different depth layers. These correlations show that a substantial quantity of alkalinity is added to the seawater during its residence time in the Mediterranean Sea, whereas the biological processes, the air-sea exchange and the high remineralization rate are responsible of the high $\mathrm{C}_{\mathrm{T}}$ concentrations in this sea. Moreover, these fits could be used to estimate the $A_{T}$ and $C_{T}$ from salinity where there are not available measurements of the carbonate system parameters.
\end{abstract}

Keywords: Carbonate System, Total Alkalinity, Total Dissolved Inorganic Carbon, Fits, Mediterranean Sea

\section{Introduction}

Aiming to understand and quantify the carbonate system in the Mediterranean Sea, several studies have been realized (e.g. [1], [2], [3], [4], [5], [6], [7]). However, the amount of high quality measurements of the carbonate system properties, particularly the total alkalinity $\left(\mathrm{A}_{\mathrm{T}}\right)$ and the total dissolved inorganic carbon $\left(\mathrm{C}_{\mathrm{T}}\right)$, through the whole Mediterranean Sea remained scarce. Recently, during several oceanographic cruises carried out from 2001 until now, the measurement of carbonate system parameters was included [5] [8] [9] [10] [11]. However, many Mediterranean sub-basins remain out of coverage and need to be studied in order to have a better understanding of the carbonate system in this enclosed sea.
The measurement of the $A_{T}$ and $C_{T}$ parameters could be furthermore used to calculate the carbon budget in the Mediterranean and to estimate the acidification variation and the concentrations of the anthropogenic carbon dioxide sequestered in this sea.

The present paper is based on $\mathrm{A}_{\mathrm{T}}$ and $\mathrm{C}_{\mathrm{T}}$ data measured during the 2013 MedSeA cruise which covered during the same month almost the entire Mediterranean Sea from the West to the East and from the South to the North. In this study, we present and discuss, for the first time, the $\mathrm{A}_{\mathrm{T}}$-Salinity and $\mathrm{C}_{\mathrm{T}}$-Salinity relationships in each Mediterranean basin and sub-basin at different depth layers. These correlations could be used to estimate the $A_{T}$ and $C_{T}$ from salinity data where there is a lack in the measurements of 
the carbonate system parameters.

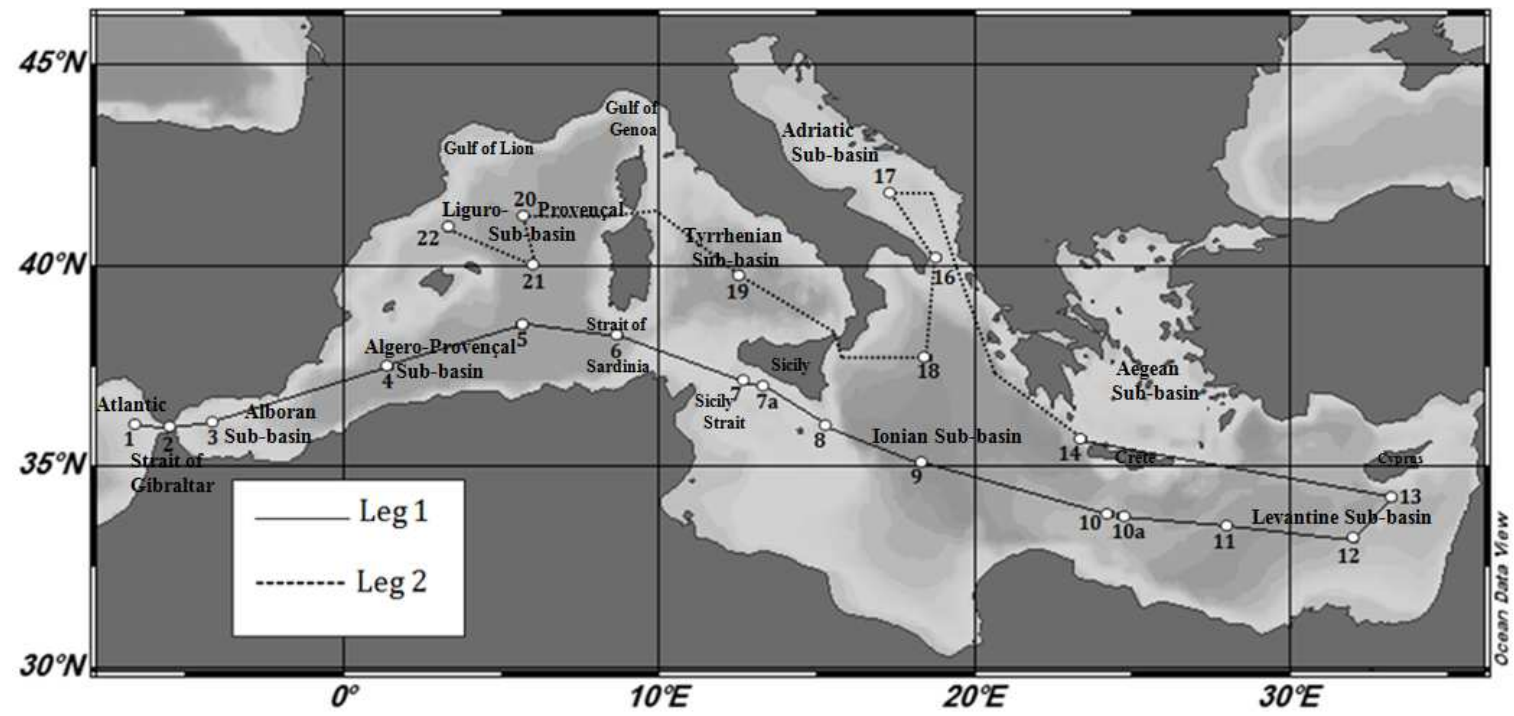

Fig. 1. Tracks of the 2013 MedSeA cruise in the Mediterranean Sea. The numbers from 1 to 22 correspond to the sampled stations.

\section{Study Area and Methodology}

\subsection{MedSeA Cruise}

During the MedSeA (Mediterranean Sea Acidification In A Changing Climate) cruise realized on board of the Spanish $\mathrm{R} / \mathrm{V}$ Angeles Alvariño, from May $2^{\text {nd }}$ to June $2^{\text {nd }} 2013,23$ stations along the Mediterranean Sea were sampled throughout the water column. The overall goal and scientific objectives of the MedSeA project are well described in the following links [12 and 13]. The full cruise track (more than $8000 \mathrm{~km}$ long) consisted of two almost longitudinal legs. During the first leg, samples were collected from Atlantic waters off Cadiz harbor, Spain to the Levantine Sub-basin in the Eastern Mediterranean Sea [3879 km long, 15 stations, 279 sampled points, maximum sampled depth $=3720 \mathrm{~m}]$. The second leg was conducted in the Northern part of the Mediterranean from the Western Cretan Straits in the Eastern Mediterranean basin to Barcelona, Spain in the North Western Mediterranean basin, passing through the South of the Adriatic Sub-basin [3232.5 km long, 8 stations, 183 sampled points, maximum sampled depth $=3000 \mathrm{~m}]$ (Figure 1).

\subsection{Sampling and Measurement}

The salinity (S) was measured in situ using a Sea-Bird Electronics CTD system (SBE 911 plus) associated with a General Oceanic rosette sampler, equipped with twenty four $12 \mathrm{~L} \mathrm{Niskin}$ bottles. The precision of salinity measurements is \pm 0.0003 .

For the determination of $\mathrm{A}_{\mathrm{T}}$ and $\mathrm{C}_{\mathrm{T}}$, seawater samples were collected, at all stations and depths, into washed $500 \mathrm{ml}$ borosilicate glass bottles, according to standard operational protocol. A small headspace $(<1 \%)$ was adjusted to prevent pressure build-up and loss of $\mathrm{CO}_{2}$ during storage. Few drops of a saturated solution of $\mathrm{HgCl}_{2}$ were added to the samples in order to avoid any biological activity. Then, the samples were stored in the dark at constant temperature $\left(\sim 4^{\circ} \mathrm{C}\right)$ until their analysis on shore (IMAGES laboratory, Perpignan, France). The measurement of these two parameters was performed simultaneously by potentiometric acid titration using a closed cell. The principle and procedure of measurements, as well as a complete description of the system used to perform accurate analysis can be found in [14]. The precision of $A_{T}$ and $C_{T}$ analysis was determined to be $\pm 2 \mu \mathrm{mol} \mathrm{kg}^{-1}$ for $\mathrm{A}_{\mathrm{T}}$ and \pm 4 $\mu \mathrm{mol} \mathrm{kg}{ }^{-1}$ for $C_{T}$, by titration of 261 samples, collected at the same conditions of temperature and $\mathrm{S}$, from Banyuls Sur Mer, South France. The accuracy of $\mathrm{A}_{\mathrm{T}}$ and $\mathrm{C}_{\mathrm{T}}$ measurements was determined to be $\pm 1 \mu \mathrm{mol} \mathrm{kg}^{-1}$ for $\mathrm{A}_{\mathrm{T}}$ and $\pm 4 \mu \mathrm{mol} \mathrm{kg}^{-1}$ for $\mathrm{C}_{\mathrm{T}}$ by analyzing a total of 26 bottles of three different batches of Certified Reference Material (Andrew Dickson, CA, USA, batches 85, 86 and 128). More information about the carbonate system measurements and precisions are detailed by [15].

The carbonate system and hydrographic data of the 2013 MedSeA cruise are almost available in Pangaea data repository [16, 17, 18, 19 and 20].

\section{Results and Discussion}

\section{1. $A_{T}-S$ Relationships in the Mediterranean Sea, its Basins and Sub-Basins}

Termed as "evaporation basin", the Mediterranean Sea is characterized by elevated salinities in relation to the adjacent Atlantic Ocean. As a consequence of the surface heat loss and the excessive evaporation [21] [22], the general pattern of salinity in the Mediterranean is an Eastward global increase (Fig.2). The highest salinity values were measured in the Eastern Mediterranean basin (Max. 39.18 in front of Nile Delta, at $\sim 5 \mathrm{~m}$ ), while the lowest salinities were detected at the surface of both the Western Mediterranean basin and the Strait of Gibraltar (Min. 36.29 at the surface of the Strait of Gibraltar, $20 \mathrm{~m}$ ). 


\section{$S$ - Western basin}

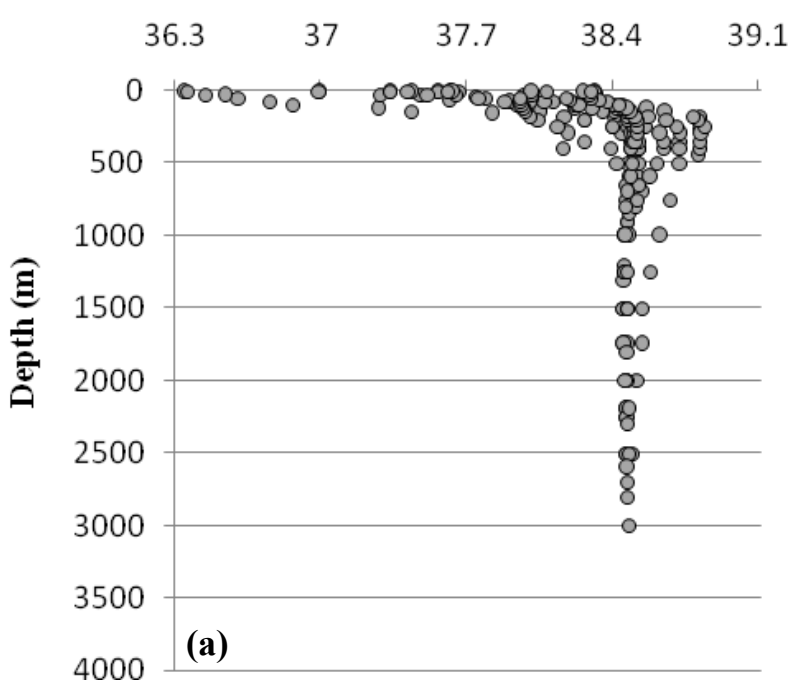

$S$ - Eastern basin

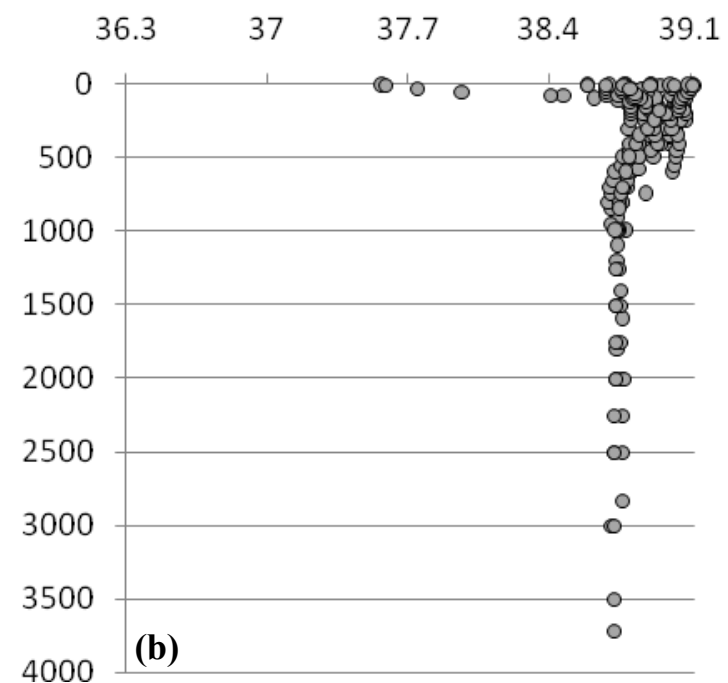

Fig. 2. Salinity (S) as a function of depth in the Western (a) and in the Eastern (b) Mediterranean basins.
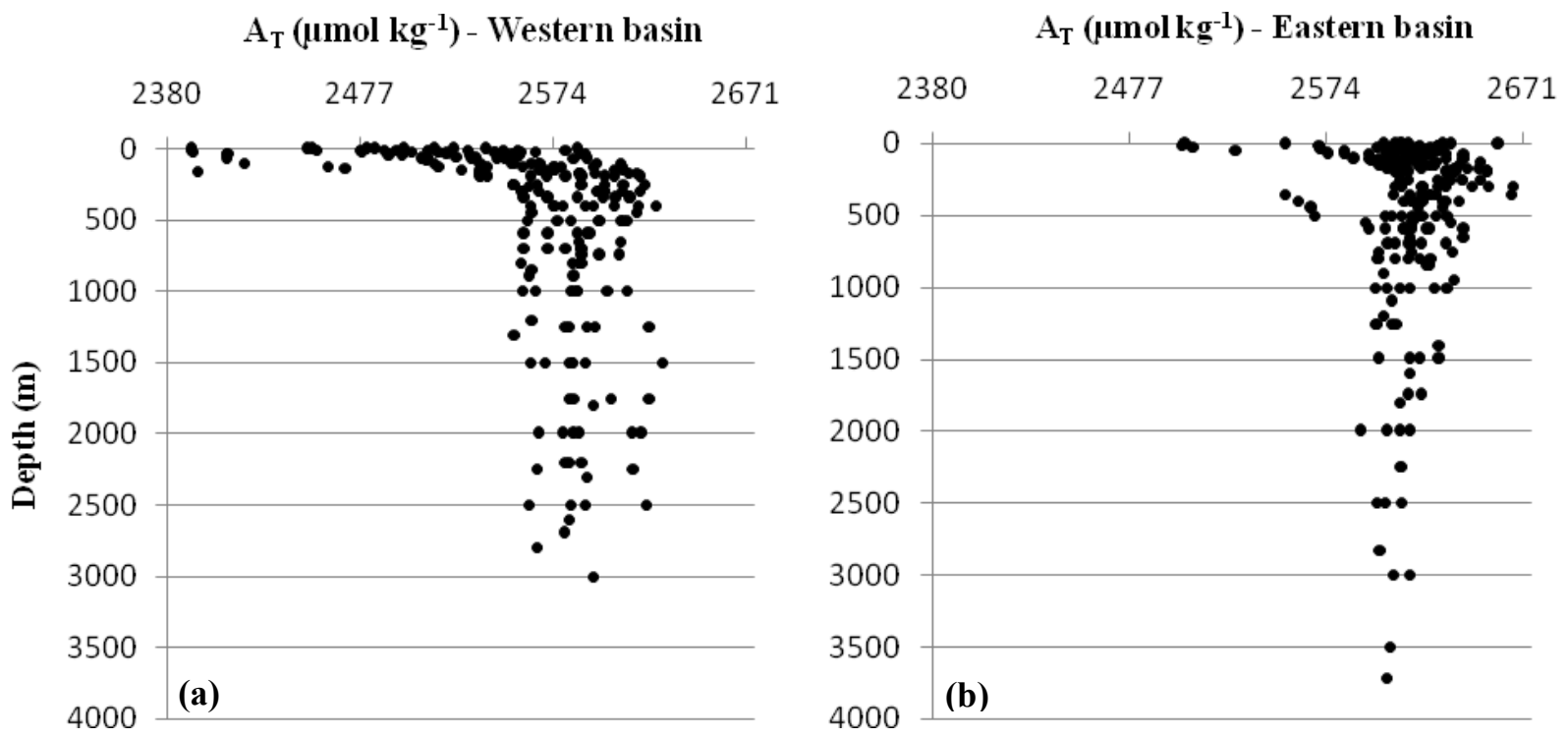

Fig. 3. Total alkalinity ( $\mu \mathrm{mol} \mathrm{kg}^{-1}$ ) as a function of depth in the Western (a) and in the Eastern (b) Mediterranean basins.

High total alkalinity concentrations were recorded in the Mediterranean Sea $\left(\right.$ Mean $\left.=2588 \pm 46 \mu \mathrm{mol} \mathrm{kg}{ }^{-1}\right)$. The highest $\mathrm{A}_{\mathrm{T}}$ concentrations were measured in the Eastern Mediterranean basin (Max. $\mathrm{A}_{\mathrm{T}}=2666.0 \mu \mathrm{mol} \mathrm{kg}{ }^{-1}$, at $300 \mathrm{~m}$ in the area of Western Cretan Straits, whereas the lowest $A_{T}$ concentrations were measured in both the Strait of Gibraltar and the surface waters of the Western Mediterranean basin (Min. $\mathrm{A}_{\mathrm{T}}=2377.0 \mu \mathrm{mol} \mathrm{kg}{ }^{-1}$ at $25 \mathrm{~m}$ in the Strait of Gibraltar). An Eastward increasing tendency for the total alkalinity was also well noticeable, likewise the salinity trend (Fig.3).

Based on the carbonate system parameters data collected during the 2013 MedSeA cruise, an Eastward increasing trend of $A_{T}$ was remarked in parallel with the salinity one [15]. Our results indicate the presence of significant correlations between $\mathrm{A}_{\mathrm{T}}$ and $\mathrm{S}$ in the Mediterranean Sea globally, its main basins and many of its sub-basins as well. Table 1 presents the Model II linear regression between these two parameters in each basin and sub-basin and at different depth layers (surface, intermediate and deep layers). These equations were obtained using the Excel Microsoft Office program (2007). For all the equations derived in this study, the root mean square deviation (RMSD), which is a good measure of the accuracy of the fit, the coefficient of correlation (Pearson coefficient ; r), and the number of data pairs (n) used to derive each correlation, are also mentioned in the Table 1 for each $\mathrm{A}_{\mathrm{T}} \mathrm{S}$ fit.

Evaporation would drive a steady increase in salinity and total alkalinity during the propagation of surface waters toward the Eastern part of the Mediterranean Sea. Therefore, the negative intercepts obtained in most $\mathrm{A}_{\mathrm{T}} \mathrm{S}$ fits (Table 1) may be explained by the high evaporation in the sea along 
with the influence of high $A_{T}$ inputs by freshwater contributions from the local rivers and the Black Sea. These two systems carry very high total alkalinities (between 2000 $\mu \mathrm{mol} \mathrm{kg}$ and $6500 \mu \mathrm{mol} \mathrm{kg}^{-1}$ ), at low or zero salinity, to shelf areas, especially in the Eastern basin, where surface $\mathrm{S}$ and $\mathrm{A}_{\mathrm{T}}$ tend to be higher due to the cumulative effects of evaporation
[5]. Moreover, our results indicate the absence of a significant $\mathrm{A}_{\mathrm{T}}-\mathrm{S}$ correlation in the intermediate and deep layers of the Eastern basin, especially in the Levantine Sub-basin in which we detected no significant $\mathrm{A}_{\mathrm{T}}$-S relationship at all depth layers (Table1).

Table 1. The A $A_{T}-S$ relationships in the different layers of the main basins and sub-basins in the Mediterranean Sea during May 2013(R.M.S.D. = root mean square deviation, $r=$ coefficient of correlation (Pearson's coefficient), $n=$ number of data pairs used to derive each relationship, [-] means that no significant relationship was found).

\begin{tabular}{|c|c|c|c|c|c|c|}
\hline Basin/Sub-basin & Depth & $\mathrm{A}_{\mathrm{T}}-\mathrm{S}$ relationships & R.M.S.D & $\mathbf{r}$ & $\mathbf{n}$ & Number of equation \\
\hline \multirow{4}{*}{ Mediterranean } & All & $\mathrm{A}_{\mathrm{T}}=98.48 * \mathrm{~S}-1208$ & \pm 19 & 0.9 & 428 & Eq. 1 \\
\hline & Surface $(0-25 \mathrm{~m})$ & $\mathrm{A}_{\mathrm{T}}=89 * \mathrm{~S}-845$ & \pm 18 & 0.96 & 58 & Eq. 2 \\
\hline & Intermediate $(>25-400 \mathrm{~m})$ & $\mathrm{A}_{\mathrm{T}}=98 * \mathrm{~S}-1191$ & \pm 18.5 & 0.91 & 208 & Eq. 3 \\
\hline & Deep $(>400 \mathrm{~m})$ & $\mathrm{A}_{\mathrm{T}}=134 * \mathrm{~S}-2578$ & \pm 17 & 0.57 & 160 & Eq. 4 \\
\hline \multirow{4}{*}{ Western basin } & All & $\mathrm{A}_{\mathrm{T}}=99 * \mathrm{~S}-1225.5$ & \pm 15.6 & 0.94 & 215 & Eq. 5 \\
\hline & Surface $(0-25 \mathrm{~m})$ & $A_{T}=92 * S-956$ & \pm 12.5 & 0.97 & 30 & Eq. 6 \\
\hline & Intermediate $(>25-400 \mathrm{~m})$ & $\mathrm{A}_{\mathrm{T}}=101.5 * \mathrm{~S}-1322$ & \pm 15.6 & 0.94 & 105 & Eq. 7 \\
\hline & Deep $(>400 \mathrm{~m})$ & - & - & - & - & - \\
\hline \multirow{4}{*}{ Eastern basin } & All & $\mathrm{A}_{\mathrm{T}}=111.42 * \mathrm{~S}-1713$ & \pm 19 & 0.54 & 212 & Eq. 8 \\
\hline & Surface $(0-25 \mathrm{~m})$ & $\mathrm{A}_{\mathrm{T}}=89 * \mathrm{~S}-846$ & \pm 19 & 0.86 & 27 & Eq. 9 \\
\hline & Intermediate $(>25-400 \mathrm{~m})$ & - & - & - & - & - \\
\hline & $\operatorname{Deep}(>400 \mathrm{~m})$ & - & - & - & - & - \\
\hline \multirow{4}{*}{ Alboran Sub-basin } & All & $\mathrm{A}_{\mathrm{T}}=81.15 * \mathrm{~S}-567.7$ & \pm 4.4 & 0.99 & 23 & Eq. 10 \\
\hline & Surface $(0-25 \mathrm{~m})$ & $\mathrm{A}_{\mathrm{T}}=10.65 * \mathrm{~S}+2005$ & \pm 0.07 & 0.98 & 3 & Eq. 11 \\
\hline & Intermediate $(>25-400 \mathrm{~m})$ & $\mathrm{A}_{\mathrm{T}}=82 * \mathrm{~S}-605.6$ & \pm 5 & 0.99 & 11 & Eq. 12 \\
\hline & Deep $(>400 \mathrm{~m})$ & $A_{T}=171 * S-4020$ & \pm 2 & 0.7 & 8 & Eq. 13 \\
\hline \multirow{4}{*}{$\begin{array}{l}\text { Algero-Provencal } \\
\text { Sub-basin }\end{array}$} & All & $\mathrm{A}_{\mathrm{T}}=98 * \mathrm{~S}-1190$ & \pm 11.7 & 0.95 & 73 & Eq. 14 \\
\hline & Surface $(0-25 \mathrm{~m})$ & $\mathrm{A}_{\mathrm{T}}=100.72 * \mathrm{~S}-1282.6$ & \pm 14 & 0.89 & 9 & Eq. 15 \\
\hline & Intermediate $(>25-400 \mathrm{~m})$ & $\mathrm{A}_{\mathrm{T}}=119.38 * \mathrm{~S}-2009.7$ & \pm 11.8 & 0.92 & 33 & Eq. 16 \\
\hline & Deep $(>400 \mathrm{~m})$ & - & - & - & - & - \\
\hline \multirow{4}{*}{$\begin{array}{l}\text { Liguro-Provencal } \\
\text { Sub-basin }\end{array}$} & All & $A_{T}=126 * S-2252$ & \pm 15 & 0.84 & 71 & Eq. 17 \\
\hline & Surface $(0-25 \mathrm{~m})$ & $\mathrm{A}_{\mathrm{T}}=93.33 * \mathrm{~S}-1008$ & \pm 12.5 & 0.9 & 9 & Eq. 18 \\
\hline & Intermediate $(>25-400 \mathrm{~m})$ & $\mathrm{A}_{\mathrm{T}}=128 * \mathrm{~S}-2327$ & \pm 11.6 & 0.89 & 31 & Eq. 19 \\
\hline & Deep $(>400 \mathrm{~m})$ & - & - & - & - & - \\
\hline \multirow{4}{*}{ Tyrrhenian Sub-basin } & All & $\mathrm{A}_{\mathrm{T}}=95.4 * \mathrm{~S}-1084.5$ & \pm 5.4 & 0.97 & 21 & Eq. 20 \\
\hline & Surface $(0-25 \mathrm{~m})$ & $\mathrm{A}_{\mathrm{T}}=339.73 * \mathrm{~S}-10384$ & \pm 3 & -0.96 & 3 & Eq. 21 \\
\hline & Intermediate $(>25-400 \mathrm{~m})$ & $\mathrm{A}_{\mathrm{T}}=96.72 * \mathrm{~S}-1139$ & \pm 4 & 0.98 & 11 & Eq. 22 \\
\hline & Deep $(>400 \mathrm{~m})$ & - & - & - & - & - \\
\hline \multirow{4}{*}{ Ionian Sub-basin } & All & $\mathrm{A}_{\mathrm{T}}=112 * \mathrm{~S}-1730$ & \pm 15 & 0.88 & 57 & Eq. 23 \\
\hline & Surface $(0-25 \mathrm{~m})$ & $\mathrm{A}_{\mathrm{T}}=97.56 * \mathrm{~S}-1173.5$ & \pm 17 & 0.95 & 8 & Eq. 24 \\
\hline & Intermediate $(>25-400 \mathrm{~m})$ & $\mathrm{A}_{\mathrm{T}}=140 * \mathrm{~S}-2818$ & \pm 16 & 0.82 & 27 & Eq. 25 \\
\hline & Deep $(>400 \mathrm{~m})$ & - & - & - & - & - \\
\hline \multirow{4}{*}{ Adriatic Sub-basin } & All & - & - & - & - & - \\
\hline & Surface $(0-25 \mathrm{~m})$ & $\mathrm{A}_{\mathrm{T}}=239.5 * \mathrm{~S}-6653.7$ & \pm 8 & -0.84 & 6 & Eq. 26 \\
\hline & Intermediate $(>25-400 \mathrm{~m})$ & - & - & - & - & - \\
\hline & Deep $(>400 \mathrm{~m})$ & - & - & - & - & - \\
\hline \multirow{4}{*}{ Western Cretan Straits } & All & - & - & - & - & - \\
\hline & Surface $(0-25 \mathrm{~m})$ & $\mathrm{A}_{\mathrm{T}}=81.28 * \mathrm{~S}-569$ & \pm 0.13 & 0.99 & 3 & Eq. 27 \\
\hline & Intermediate $(>25-400 \mathrm{~m})$ & - & - & - & - & - \\
\hline & Deep $(>400 \mathrm{~m})$ & $\mathrm{A}_{\mathrm{T}}=1236.95 * \mathrm{~S}-45690$ & \pm 6.3 & -0.88 & 4 & Eq. 28 \\
\hline \multirow{4}{*}{ Levantine Sub-basin } & All & - & - & - & - & - \\
\hline & Surface $(0-25 \mathrm{~m})$ & - & - & - & - & - \\
\hline & Intermediate $(>25-400 \mathrm{~m})$ & - & - & - & - & - \\
\hline & $\operatorname{Deep}(>400 \mathrm{~m})$ & - & - & - & - & - \\
\hline
\end{tabular}

In addition, our results reveal the presence of a very strong positive $\mathrm{A}_{\mathrm{T}}-\mathrm{S}$ correlation (Eq.27) in the surface layer of the Western Cretan Straits, whereas in the deep layer a significant negative $\mathrm{A}_{T}-\mathrm{S}$ correlation is observed (Eq.28). It is also shown the presence of a negative and significant $\mathrm{A}_{\mathrm{T}}-\mathrm{S}$ fit exclusively in the surface layer of the Adriatic Sub-basin (Eq.26; Table 1). These remarks demonstrate that the relationship between $\mathrm{S}$ and $\mathrm{A}_{\mathrm{T}}$ does not follow the Eastward strict evaporation trend. However, it reflects the mixture of waters characterized by high $\mathrm{A}_{\mathrm{T}}$ concentrations with low salinity waters in the Eastern part of the Eastern Sub-basins and in the Adriatic Sub-basin. This fact is explained by the mixing, between high salinity surface water in the Eastern Sub-basins with waters from rivers flowing through carbonate-dominated terrains and/or the Black Sea, that change the characteristics of surface waters which become less saline with higher $\mathrm{A}_{\mathrm{T}}$ concentrations.

Our $\mathrm{A}_{\mathrm{T}} \mathrm{S}$ equation (Eq.1), that takes into account all available data pairs of both parameters in the entire 
Mediterranean basin, is very similar to the one published by [23]: $\mathrm{A}_{\mathrm{T}}=99.6 * \mathrm{~S}-1238.4 \pm 4.5 \mu \mathrm{mol} \mathrm{kg}{ }^{-1}$ (Eq.I), obtained using all the available data in the DYFAMED site in the North-Western basin of the Mediterranean Sea from 1998 to 2005. The reason for the slightly less steep slope and the less negative intercept in our correlation (Eq.1) compared to the other one (Eq.I) could be attributed to the difference of sampling locations (different specific total alkalinities between the Western and the Eastern basins). Located in the North-Western Mediterranean basin $\left(43^{\circ} 25^{\prime} \mathrm{N}, 07^{\circ} 52^{\prime} \mathrm{E}\right)$, the DYFAMED site is more influenced by the contributions of waters coming from the continents than most of the stations of the 2013 MedSeA cruise (Fig.1). In the coastal zone, total alkalinity inputs by rivers (ex. the nearby Rhone has an $\mathrm{A}_{\mathrm{T}}=$ $2885 \mu \mathrm{mol} \mathrm{kg}^{-1}$ [5]) and potentially by sediments, may induce the steep slope of the regression line.

In the Alboran Sub-basin, a positive and highly significant $\mathrm{A}_{\mathrm{T}}-\mathrm{S}$ correlation was detected (Table 1). This is attributed firstly to the parallel increase of salinity and $A_{T}$ of the surface Atlantic waters incoming towards the Mediterranean Sea, and secondly, to the high $\mathrm{S}$ and $\mathrm{A}_{\mathrm{T}}$ in the outgoing Mediterranean waters toward the Atlantic at the deepest layers. In addition, it was noted that the $\mathrm{A}_{\mathrm{T}}$-S fit (Eq.10) obtained based on all the data collected in the Alboran Sub-basin, is different from the one mentioned by [4] in the same sub-basin: $A_{T}=94.85 * \mathrm{~S}-$ $1072.6 \mu \mathrm{mol} \mathrm{kg}{ }^{-1}$ (Eq.II). This may be due to the large difference in the number of sampled points (23 in our study $v s$. 440 in [4]) and the time difference of 25 years between the sampling dates of the two studies. Therefore, the observed differences between Eq.10 and the equation of [4] could also be attributed to the temporal variability of the temperature and $\mathrm{S}$, related to the climate change, in the Mediterranean Sea [24] [25] [26] [27].

Similarly, a positive and highly significant $\mathrm{A}_{\mathrm{T}}-\mathrm{S}$ correlation was noted in the deepest and most isolated sub-basin of the Western basin, the Tyrrhenian Sub-basin. The circulation patterns of the Mediterranean Sea show generally that most of the saline and high- $\mathrm{A}_{\mathrm{T}}$ water, coming from the East to the Western basin, enters the Tyrrhenian Sub-basin [28]. Below the surface modified Atlantic waters, the Tyrrhenian Sub-basin is the first Western Sub-basin reached by the Levantine Intermediate Waters (LIW), coming from the Eastern basin through the Sicily Channel. The LIW enters the Tyrrhenian Sub-basin along the slope of Sicily and leaves it along the Sardinian coast [29]. The fact that the intermediate layer of this sub-basin is occupied by the LIW explains the positive and very significant correlation between $\mathrm{A}_{T}$ and $\mathrm{S}$ in the intermediate depths of the Tyrrhenian. Our $\mathrm{A}_{\mathrm{T}}-\mathrm{S}$ fit (Eq.20), obtained by all the available data of the Tyrrhenian Sub-basin, is similar to the one recorded by [8]: $\mathrm{A}_{\mathrm{T}}=96.62 * \mathrm{~S}$ - $1139.1 \mu \mathrm{mol} \mathrm{kg}{ }^{-1}$ (Eq.III). The slight differences in the slopes and intercepts between the two equations are due firstly to the different number of stations and sampled points (one station and $\mathrm{n}=21$ in our study $v s$. six stations and $\mathrm{n}=320$ in the other one), and secondly to the date of sampling (May 2013 in our study, November 2006, February, April and July 2007 and February 2008 in the other one).
The $\mathrm{A}_{\mathrm{T}}-\mathrm{S}$ correlation (Eq.2) for the surface layer of the entire Mediterranean Sea differs from the regression reported by [5]: $\mathrm{A}_{\mathrm{T}}=73.7 * \mathrm{~S}-285.7 \pm 8.20 \mu \mathrm{mol} \mathrm{kg} \mathrm{kg}^{-1}$ (Eq. IV). The reason for the steeper slope and the more negative intercept in Eq.2 compared to Eq.IV, could be attributed to the different sampling locations : our track passed through the Strait of Gibraltar toward the Eastern part of the Mediterranean Sea and the stations were equally distributed between the two main Mediterranean basins, while the track covered in the other study was conducted from the South-East of Sardinia toward the Levantine Sub-basin and the sampled stations were concentrated mainly in the Eastern basin. In addition, the sampling periods were different: the data of the present study were collected in May 2013, whereas the data of [5] were sampled in October/November 2001. The differentiation in Eq.2 and Eq.IV could thus be attributed to the temporal variability of temperature and $\mathrm{S}$ in the Mediterranean Sea, which is in part associated to the climate change (as mentioned above for the Alboran Sub-basin). Equation 2 also differs from the recently reported $\mathrm{A}_{\mathrm{T}}-\mathrm{S}$ fit $(\mathrm{Eq} . \mathrm{V})$ for Mediterranean surface waters reported by [30]: $\mathrm{A}_{\mathrm{T}}=79.84 * \mathrm{~S}-510(\mathrm{Eq} . \mathrm{V})$ that was based exclusively on measurements made at $5 \mathrm{~m}$ below the sea surface.

Furthermore, the $\mathrm{A}_{\mathrm{T}} \mathrm{S}$ relationships noted for the surface waters of the entire Mediterranean Sea (Eq.2) and specifically for the surface waters of the Western basin (Eq.6), are very close to the relationship: $\mathrm{A}_{\mathrm{T}}=93.996 * \mathrm{~S}-1038.1 \pm 2.5 \mu \mathrm{mol}$ $\mathrm{kg}^{-1}$ (Eq.VI), calculated for samples located between the surface and the maximum of salinity (LIW horizon) at the DYFAMED site [31].

The abovementioned similarities of $\mathrm{A}_{\mathrm{T}}-\mathrm{S}$ correlations in the different Mediterranean areas, imply that the $\mathrm{A}_{T}$ could considered to be conservative in the Mediterranean Sea, as previously was stated by [32]. The conservative behavior of $\mathrm{A}_{\mathrm{T}}$ with respect to salinity occurs because $\mathrm{HCO}_{3}{ }^{-}$(which is, together with $\mathrm{CO}_{3}{ }^{2-}$ and $\mathrm{B}(\mathrm{OH})_{4}{ }^{-}$, one of the most important bases for seawater) is a major constituent of seawater and the ratio of $\mathrm{HCO}_{3}{ }^{-}$to the salinity or the chlorinity is nearly constant [8]. Equations 5 and 8 describing the $\mathrm{A}_{\mathrm{T}}-\mathrm{S}$ relationship in the Western and Eastern Mediterranean basins, respectively, are considerably different although both have negative intercepts. The slope and the absolute intercept values are higher in the Eastern basin, indicating that the salinity-specific alkalinity (i.e. $\mathrm{A}_{\mathrm{T}} / \mathrm{S}$ ratio) increases with salinity. The specific alkalinity of the Eastern Mediterranean waters is therefore higher than that of less saline Western ones. As the regression lines do not pass through the origin, the different values of the intercept between the different $A_{T}-S$ equations (Table 1) reflect the different specific total alkalinities of the Eastern and Western Mediterranean water masses due to the contributions to $\mathrm{A}_{\mathrm{T}}$ besides the salinity. However, excessive inputs of $\mathrm{A}_{\mathrm{T}}$ from rivers in the Adriatic Sub-basin [33] result in the absence of a significant correlation between $\mathrm{A}_{\mathrm{T}}$ and $\mathrm{S}$ at all the depths of this sub-basin, except on the surface layer where a significant but negative $A_{T}-S$ fit was detected. The mixing of saline surface water, coming from the Eastern Sub-basins with local waters discharged by the nearby 
rivers and characterized by very high $\mathrm{A}_{\mathrm{T}}$ concentrations, shaping the specific fit.

\section{2. $C_{T}-S$ Relationships in the Mediterranean Sea, its Basins and Sub-Basins}

Total dissolved inorganic carbon $\left(\mathrm{C}_{\mathrm{T}}\right)$ varied between a minimum of $2095 \mu \mathrm{mol} \mathrm{kg}{ }^{-1}$ at the surface layers $(\sim 5 \mathrm{~m})$ of the Alboran Sub-basin in the Western Mediterranean basin and a

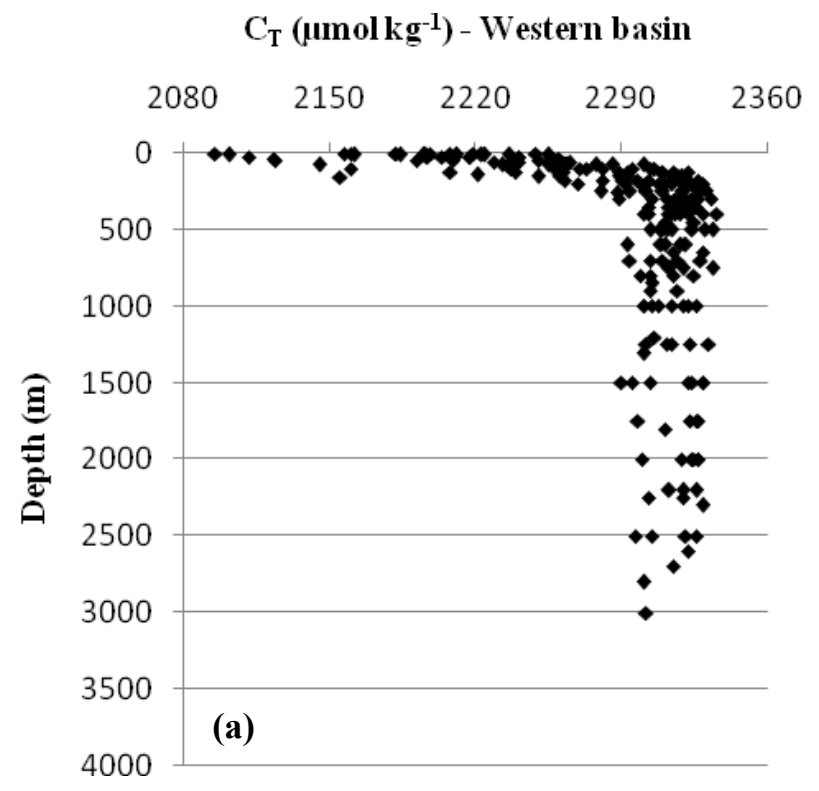

maximum of $2359.0 \pm 0.4 \mu \mathrm{mol} \mathrm{kg}{ }^{-1}$ in the intermediate waters $(\sim 350 \mathrm{~m})$ of the Eastern Mediterranean basin (Mean $=2308.5$ $\pm 22 \mu \mathrm{mol} \mathrm{kg}{ }^{-1}$, Fig.4). However, it is obvious that the intermediate, deep and bottom layers of the Western basin are characterized by the highest $\mathrm{C}_{\mathrm{T}}$ concentrations $(2321 \pm 12$ $\mu \mathrm{mol} \mathrm{kg}{ }^{-1}$ in the intermediate layers of the Algero-Provencal Sub-basin and $2322.0 \pm 0.0 \mu \mathrm{mol} \mathrm{kg}{ }^{-1}$ in the deep layers of the Liguro-Provencal Sub-basin) compared to the Eastern basin.

Fig. 4. Total inorganic carbon ( $\mu \mathrm{mol} \mathrm{kg}^{-1}$ ) as a function of depth in the Western (a) and in the Eastern (b) Mediterranean Basins.

The presence of high $\mathrm{C}_{\mathrm{T}}$ concentrations in conjunction with high salinities (Fig.2 and 4) in both the Eastern and the Western Mediterranean basins explains the general significant correlation obtained between these two parameters in the entire Mediterranean Sea. Up to our knowledge, the $\mathrm{C}_{\mathrm{T}}-\mathrm{S}$ equations are not assessed for all the Mediterranean basins and sub-basins and at different depth layers (surface, intermediate and deep). The Table 3 presents the $\mathrm{C}_{\mathrm{T}} \mathrm{S}$ fits in the different layers of the main basins and sub-basins in the Mediterranean Sea obtained by linear regression of Model II, using the data of the 2013 MedSeA cruise.

The variability of $\mathrm{C}_{\mathrm{T}}$, apart of salinity, is also controlled by biological processes (i.e. precipitation and dissolution of calcium carbonate, photosynthesis, oxidation of organic matters), and the air-sea exchange of carbon dioxide. Due to the additional impact of these non-conservative processes on $\mathrm{C}_{\mathrm{T}}$, significant $\mathrm{C}_{\mathrm{T}}-\mathrm{S}$ correlations are not obtained at all depth layers. In the Eastern basin, there is no significant relationship between these two parameters in the intermediate layer, but we have noted a significant and negative $\mathrm{C}_{\mathrm{T}}-\mathrm{S}$ fit (Eq.8) in the deep layers. The deep waters of this basin are characterized by high $\mathrm{C}_{\mathrm{T}}$ concentrations and relatively low salinities in relation to the overlying layers, which explain the negative $\mathrm{C}_{\mathrm{T}}-\mathrm{S}$ correlation. In the Mediterranean Sea, the convective processes and the consequent advection of dense waters assume a relevant role in sustaining the amount of remineralization in deep layers and appear to be more important than the sinking of particulate matter from the upper layers [34]. It is evident that the active overturning circulation of the Mediterranean Sea fuels the deep layers with labile carbon entrained in the newly formed deep waters inducing enhanced production of respiratory $\mathrm{CO}_{2}$. The involvement of remineralization explains the high $\mathrm{C}_{\mathrm{T}}$ concentrations measured in the deep layers of both the Eastern and the Western basins and the absence of a significant $\mathrm{C}_{\mathrm{T}}-\mathrm{S}$ correlation in the deep layers of many Mediterranean sub-basins (Table 2).

Our $\mathrm{C}_{\mathrm{T}^{-}} \mathrm{S}$ correlations at the surface (Eq.17) and intermediate (Eq.18) layers of the Liguro-Provencal Sub-basin are different from the ones reported by [32]. However, it has to be mentioned that the $\mathrm{C}_{\mathrm{T}}-\mathrm{S}$ relationships obtained by the two studies are not totally comparable. The differences could be attributed to the different sampling strategy ; the equations of [32] are based on data collected in one fixed station in a coastally-influenced area (DYFAMED site) that was sampled monthly for a 2-years period, whereas the equations of the present study derived from data collected in May 2013 in three sampling stations. In addition, the data used in the study of [32] are originating from different depth intervals than ours: the relationship $\left[\mathrm{C}_{\mathrm{T}}=74.53 * \mathrm{~S}-555.2 \mu \mathrm{mol} \mathrm{kg}{ }^{-1}\right]$ corresponds to depths below the salinity maximum (LIW horizon) down to the bottom and the equation $\left[\mathrm{C}_{\mathrm{T}}=155.17 * \mathrm{~S}-3662.6 \mu \mathrm{mol}\right.$ $\left.\mathrm{kg}^{-1}\right]$ was calculated for samples located between the surface and the maximum of salinity in wintertime. 
Table 2. The $C_{T}$-S relationships in the different layers of the main basins and sub-basins in the Mediterranean Sea during May 2013(R.M.S.D. = root mean square deviation, $r=$ coefficient of correlation (Pearson's coefficient), $n=$ number of data pairs used to derive each relationship, [-] means that no significant relationship was found).

\begin{tabular}{|c|c|c|c|c|c|c|}
\hline Basin/Sub-basin & Depth & $\mathrm{C}_{\mathrm{T}}-\mathrm{S}$ correlation & R.M.S & $\mathbf{r}$ & $\mathbf{n}$ & Number of equation \\
\hline \multirow{4}{*}{ Mediterranean } & All & $\mathrm{C}_{\mathrm{T}}=90.91 * \mathrm{~S}-1213$ & \pm 29 & 0.72 & 428 & Eq. 1 \\
\hline & Surface $(0-25 \mathrm{~m})$ & $\mathrm{C}_{\mathrm{T}}=63.65 * \mathrm{~S}-198$ & \pm 18 & 0.93 & 58 & Eq. 2 \\
\hline & Intermediate $(>25-400 \mathrm{~m})$ & $\mathrm{C}_{\mathrm{T}}=80.75 * \mathrm{~S}-822$ & \pm 26.5 & 0.69 & 207 & Eq. 3 \\
\hline & Deep $(>400 \mathrm{~m})$ & - & - & - & - & - \\
\hline \multirow{4}{*}{ Western basin } & All & $C_{T}=107.68 * S-1836.6$ & \pm 19 & 0.93 & 215 & Eq. 4 \\
\hline & Surface $(0-25 \mathrm{~m})$ & $\mathrm{C}_{\mathrm{T}}=74 * \mathrm{~S}-583.5$ & \pm 14 & 0.94 & 30 & Eq. 5 \\
\hline & Intermediate $(>25-400 \mathrm{~m})$ & $\mathrm{C}_{\mathrm{T}}=99.3 * \mathrm{~S}-1515$ & \pm 18 & 0.91 & 105 & Eq. 6 \\
\hline & Deep $(>400 \mathrm{~m})$ & - & - & - & - & - \\
\hline \multirow{4}{*}{ Eastern basin } & All & - & - & - & - & - \\
\hline & Surface $(0-25 \mathrm{~m})$ & $C_{T}=66 * S-292.6$ & \pm 20 & 0.68 & 28 & Eq. 7 \\
\hline & Intermediate $(>25-400 \mathrm{~m})$ & - & - & - & - & - \\
\hline & Deep $(>400 \mathrm{~m})$ & $C_{T}=269.6 * S-8145.8$ & \pm 16 & -0.53 & 81 & Eq. 8 \\
\hline \multirow{4}{*}{ Alboran Sub-basin } & All & $\mathrm{C}_{\mathrm{T}}=97.84 * \mathrm{~S}-1456.5$ & \pm 7.6 & 0.99 & 23 & Eq. 9 \\
\hline & Surface $(0-25 \mathrm{~m})$ & $\mathrm{C}_{\mathrm{T}}=148 * \mathrm{~S}-3282$ & \pm 4 & 0.83 & 3 & Eq. 10 \\
\hline & Intermediate $(>25-400 \mathrm{~m})$ & $\mathrm{C}_{\mathrm{T}}=102 * \mathrm{~S}-1611$ & \pm 5 & 0.99 & 11 & Eq. 11 \\
\hline & Deep $(>400 \mathrm{~m})$ & $\mathrm{C}_{\mathrm{T}}=244 * \mathrm{~S}-7083$ & \pm 2 & 0.87 & 8 & Eq. 12 \\
\hline \multirow{4}{*}{$\begin{array}{l}\text { Algero-Provencal } \\
\text { Sub-basin }\end{array}$} & All & $\mathrm{C}_{\mathrm{T}}=123.78 * \mathrm{~S}-2445.5$ & \pm 13.7 & 0.95 & 73 & Eq. 13 \\
\hline & Surface $(0-25 \mathrm{~m})$ & $\mathrm{C}_{\mathrm{T}}=85.61 * \mathrm{~S}-1012$ & \pm 12 & 0.88 & 9 & Eq. 14 \\
\hline & Intermediate $(>25-400 \mathrm{~m})$ & $C_{T}=136.62 * S-2934.5$ & \pm 12 & 0.93 & 32 & Eq. 15 \\
\hline & Deep $(>400 \mathrm{~m})$ & - & - & - & - & - \\
\hline \multirow{4}{*}{$\begin{array}{l}\text { Liguro-Provencal } \\
\text { Sub-basin }\end{array}$} & All & $C_{T}=143 * S-2904$ & \pm 18 & 0.83 & 70 & Eq. 16 \\
\hline & Surface $(0-25 \mathrm{~m})$ & $\mathrm{C}_{\mathrm{T}}=56.89 * \mathrm{~S}+66$ & \pm 5.6 & 0.95 & 8 & Eq. 17 \\
\hline & Intermediate $(>25-400 \mathrm{~m})$ & $\mathrm{C}_{\mathrm{T}}=113.5 * \mathrm{~S}-2059$ & \pm 13.6 & 0.8 & 33 & Eq. 18 \\
\hline & Deep $(>400 \mathrm{~m})$ & - & - & - & - & - \\
\hline \multirow{4}{*}{ Tyrrhenian Sub-basin } & All & $C_{T}=126.6 * S-2285$ & \pm 8 & 0.96 & 21 & Eq. 19 \\
\hline & Surface $(0-25 \mathrm{~m})$ & $\mathrm{C}_{\mathrm{T}}=335.17 * \mathrm{~S}-10537$ & \pm 3 & -0.95 & 3 & Eq. 20 \\
\hline & Intermediate $(>25-400 \mathrm{~m})$ & $C_{T}=103.24 * S-1683.5$ & \pm 5.26 & 0.97 & 11 & Eq. 21 \\
\hline & Deep $(>400 \mathrm{~m})$ & - & - & - & - & - \\
\hline \multirow{4}{*}{ Ionian Sub-basin } & All & $\mathrm{C}_{\mathrm{T}}=111 * \mathrm{~S}-2003$ & \pm 21 & 0.77 & 57 & Eq. 22 \\
\hline & Surface $(0-25 \mathrm{~m})$ & $\mathrm{C}_{\mathrm{T}}=72.71 * \mathrm{~S}-540$ & \pm 16 & 0.91 & 8 & Eq. 23 \\
\hline & Intermediate $(>25-400 \mathrm{~m})$ & $\mathrm{C}_{\mathrm{T}}=149 * \mathrm{~S}-3481$ & \pm 23.6 & 0.61 & 27 & Eq. 24 \\
\hline & Deep $(>400 \mathrm{~m})$ & - & - & - & - & - \\
\hline \multirow{4}{*}{ Adriatic Sub-basin } & All & - & - & - & - & - \\
\hline & Surface $(0-25 \mathrm{~m})$ & - & - & - & - & - \\
\hline & Intermediate $(>25-400 \mathrm{~m})$ & - & - & - & - & - \\
\hline & Deep $(>400 \mathrm{~m})$ & - & - & - & - & - \\
\hline \multirow{4}{*}{ Western Cretan Straits } & All & - & - & - & - & - \\
\hline & Surface $(0-25 \mathrm{~m})$ & - & - & - & - & - \\
\hline & Intermediate $(>25-400 \mathrm{~m})$ & - & - & - & - & - \\
\hline & Deep $(>400 \mathrm{~m})$ & $\mathrm{C}_{\mathrm{T}}=104.18 * \mathrm{~S}-1805$ & \pm 0.8 & -0.68 & 4 & Eq. 25 \\
\hline \multirow{4}{*}{ Levantine Sub-basin } & All & - & - & - & - & - \\
\hline & Surface $(0-25 \mathrm{~m})$ & $\mathrm{C}_{\mathrm{T}}=39.22 * \mathrm{~S}+1082$ & \pm 4 & -0.54 & 4 & Eq. 26 \\
\hline & Intermediate $(>25-400 \mathrm{~m})$ & - & - & - & - & - \\
\hline & Deep $(>400 \mathrm{~m})$ & - & - & - & - & - \\
\hline
\end{tabular}

Our results showed that the total alkalinity and total inorganic carbon were higher in the Mediterranean outflow than in the Atlantic inflow, in agreement with [35]. It seems that there is an important flux of $\mathrm{C}_{\mathrm{T}}$ from the Mediterranean to the Atlantic (at the Strait of Gibraltar, $\mathrm{C}_{\mathrm{T}}$ is equal to $2327 \pm$ $2 \mu \mathrm{mol} \mathrm{kg}^{-1}$ in the outflowing Mediterranean waters vs. $2123 \pm$ $7 \mu \mathrm{mol} \mathrm{kg}{ }^{-1}$ in the inflowing Atlantic waters). This is probably due to the supply of carbon by the rivers and the Black Sea, to the transformation of $40 \%$ of the organic carbon entering the
Mediterranean to inorganic carbon [4] and to the high remineralization rates in the Mediterranean deep layers [34]. Moreover, our results confirm that the Mediterranean Sea exports $\mathrm{C}_{\mathrm{T}}$ to the Atlantic Ocean. These findings are in agreement with those of [36] whom estimated that there is a net export of inorganic carbon from the Mediterranean Sea to the Atlantic Ocean varying from 0.02 to $0.07 \mathrm{pg} \mathrm{C} \mathrm{yr}^{-1}$, whereas [37] estimated that this export amounted to 0.025 $\mathrm{PgCyr}^{-1}$. 


\section{Conclusion}

Based on high quality and recent carbonate system data collected on May 2013 during the MedSeA cruise, this paper provides for the first time $\mathrm{A}_{\mathrm{T}}-\mathrm{S}$ and $\mathrm{C}_{\mathrm{T}}-\mathrm{S}$ fits in each Mediterranean basin and sub-basin and at different depth layers. These equations could be used to estimate, based on salinity data, the carbonate system parameters in cases where there is a lack in this kind of measurements. This study show that a substantial quantity of alkalinity is added to the seawater during its residence time in the Mediterranean Sea, whereas the biological processes, the air-sea exchange and the high remineralization rate are responsible of the high $C_{T}$ concentrations in this sea.

A continuous monitoring of the $\mathrm{CO}_{2}$ system parameters in the main sub-basins of the Mediterranean Sea is recommended to evaluate the spatial and temporal evolution of this system in the context of climate change and ocean acidification.

\section{Acknowledgements}

This work is an essential part of the European project "Mediterranean Sea Acidification in a changing climate MedSeA" (http://medsea-project.eu/), funded by the EC FP7 Cooperation program (grant agreement 265103). The authors are pleased to thank the captain and the crew of the Spanish research vessel R/V Ángeles Alvariño. Authors are grateful to the National Council for Scientific Research (CNRS) in Lebanon for the PhD thesis scholarship granted to A.E.R. HASSOUN and E. GEMAYEL.

\section{References}

[1] Alekin O.A., 1972. Saturation of Mediterranean Sea water with calcium carbonate. Geochemistry, 206, 239-242.

[2] Chernyakova A.M., 1976. Elements of the carbonate system in the Straits of Sicily (Tunis Strait) area. Oceanology, 16, 36-39.

[3] Millero F.J., Morse J., Chen C.-T.,1979. The carbonate system in the western Mediterranean Sea. Deep Sea Research Part A : Oceanographic Research Papers, 26 (12), 1395-1404.

[4] Copin-Montégut C., 1993. Alkalinity and carbon budgets in the Mediterranean Sea. Global Biogeochemical Cycles, 7 (4), 915-925, doi:10.1029/93GB01826.

[5] Schneider A., Wallace D.W.R., and Körtzinger A., 2007. Alkalinity of the Mediterranean Sea. Geophysical Research Letters, 34, L15608, doi:10.1029/2006GL028842.

[6] Schneider A., Tanhua T., Körtzinger A., Wallace D.W.R., 2010. High anthropogenic carbon content in the eastern Mediterranean. Journal of Geophysical Research, 115, C12050, doi:10.1029/2010JC006171.

[7] De Carlo E.H., Mousseau L., Passafiume O., Drupp P.S., Gattuso J., 2013. Carbonate chemistry and air-sea CO2 flux at a fixed point in a NW Mediterranean bay over a four-year period: 2007-2011. Aquatic Geochemistry, 19, 399-442.

[8] Rivaro P., Messa R., Massolo S., Frache R., 2010. Distributions of carbonate properties along the water column in the
Mediterranean Sea: Spatial and temporal variations. Marine Chemistry, 121, 236-245.

[9] Touratier F. and Goyet C., 2011. Impact of the Eastern Mediterranean Transient on the distribution of anthropogenic $\mathrm{CO} 2$ and first estimate of acidification for the Mediterranean Sea. Deep Sea Research Part I: Oceanographic Research Papers, 58,1-15.

[10] Pujo-Pay M., Conan P., Oriol L., Cornet-Barthaux V., Falco C., Ghiglione J.F., Goyet C., Moutin T., and Prieur L., 2011. Integrated survey of elemental stoichiometry $(\mathrm{C}, \mathrm{N}, \mathrm{P})$ from the western to eastern Mediterranean Sea. Biogeosciences, 8, 883-899.

[11] Álvarez M., Sanleón-Bartolomé H., Tanhua T., Mintrop L., Luchetta A., Cantoni C., Schroeder K., and Civitarese G., 2014. The $\mathrm{CO} 2$ system in the Mediterranean Sea : a basin wide perspective. Ocean Science, 10, 69-92.

[12] MedSeA (Mediterranean Sea Acidification in a changing climate) project, 2015: http://medsea-project.eu/

[13] 2013 MedSeA research cruise on ocean acidification and warming: http://medseaoceancruise.wordpress.com/

[14] DOE, 1994. Handbook of methods for the analysis of the various parameters of the carbon dioxide system in sea water ; version 2, A. G. Dickson \& C. Goyet, eds., ORNL/CDIAC-74.

[15] Hassoun A.E.R., 2014. Analyse et Modélisation de l'Acidification en Mer Méditerranée. Thèse de doctorat soutenue le 29 septembre 2014 à l'Université de Perpignan Via Domitia, laboratoire IMAGES : https://tel.archives-ouvertes.fr/tel-01083406.

[16] Goyet C., Hassoun A.E.R., Gemayel E., 2015. Carbonate system during the May 2013 MedSeA cruise. Dataset \#841933 (DOI registration in progress).

[17] Goyet C., Gemayel E., Hassoun A.E.R., 2015. Underway pCO2 in surface water during the 2013 MedSEA cruise. Dataset \#841928 (DOI registration in progress).

[18] Ziveri P., and Grelaud M., 2013. Continuous thermosalinograph oceanography along Ángeles Alvariño cruise track MedSeA2013. Universitat Autònoma de Barcelona, doi:10.1594/PANGAEA.822153.

[19] Ziveri P., and Grelaud M., 2013. Physical oceanography during Ángeles Alvariño cruise MedSeA2013. Universitat Autònoma de Barcelona, doi:10.1594/PANGAEA.822162.

[20] Ziveri P., and Grelaud M., 2013. Physical oceanography measured on water bottle samples during Ángeles Alvariño cruise MedSeA2013. Universitat Autònoma de Barcelona, doi:10.1594/PANGAEA.822163.

[21] Mariotti A., Struglia M.V., Zeng N., Lau K.-M., 2002. The Hydrological Cycle in the Mediterranean Region and Implications for the Water Budget of the Mediterranean Sea. Journal of Climate, 15, 1674-1690.

[22] Bergamasco A. and Malanotte-Rizzoli P., 2010. The circulation of the Mediterranean Sea: a historical review of experimental investigations. Advances in Oceanography and Limnology, 1 (1), 11-28.

[23] Touratier F. and Goyet C., 2009. Decadal evolution of anthropogenic $\mathrm{CO} 2$ in the northwestern Mediterranean Sea from the mid-1990s to the mid-2000s. Deep Sea Research Part I: Oceanographic Research Papers, 56 (10), 1708-1716. 
[24] Béthoux J. P., Gentili B., Raunet J., and Tailliez D., 1990. Warming trend in the western Mediterranean deep water. Nature, 347, 660-662, doi: 10.1038/347660a0.

[25] Cacho I., Grimalt J.O., Canals M., Sbaffi L., Shackleton N.J., Schönfeld J., and Zahn R., 2001. Variability of the western Mediterranean Sea surface temperature during the last 25,000 years and its connection with the Northern Hemisphere climatic changes. Paleoceanography, 16 (1), 40-52, doi:10.1029/2000PA000502.

[26] Tsimplis M.N., and Rixen M., 2002. Sea level in the Mediterranean Sea -The contribution of temperature and salinity changes. Geophysical Research Letters, 0094-8276.

[27] Skliris N., Sofianos S., Gkanasos A., Mantziafou A., Vervatis V., Axaopoulos P. and Lascaratos A., 2011. Decadal scale variability of sea surface temperature in the Mediterranean Sea in relation to atmospheric variability. Ocean Dynamics, 62 (1), 13-30, doi: 10.1007/s10236-011-0493-5.

[28] Sparnocchia S., Gasparini G.P., Astraldi M., Borghini M., Pistek P., 1999. Dynamics and mixing of the Eastern Mediterranean outflow in the Tyrrhenian Sea. Journal of Marine Systems, 20, 301-317.

[29] Budillon G., Gasparini G.P. and Schröder K., 2009. Persistence of an eddy signature in the central Tyrrhenian basin. Deep Sea Research Part II: Topical Studies in Oceanography, 56, 713-724.

[30] Jiang Z.-P., Tyrrell T., Hydes D.J., Dai M., and Hartman S.E., 2014. Variability of alkalinity and the alkalinity-salinity relationship in the tropical and subtropical surface ocean, Global Biogeochemical Cycles, 28, doi:10.1002/2013GB004678.
[31] Copin-Montégut C. and Bégovic M., 2002. Distributions of carbonate properties and oxygen along the water column $(0-$ $2000 \mathrm{~m}$ ) in the central part of the NW Mediterranean Sea (Dyfamed site). Influence of winter vertical mixing on air - sea $\mathrm{CO} 2$ and $\mathrm{O} 2$ exchanges. Deep-Sea Research, II. Topical studies in oceanography, 49 (11), 2049-2066.

[32] Bégovic M. and Copin-Montégut C., 2002. Processes controlling annual variations in the partial pressure of $\mathrm{CO} 2$ in surface waters of the central northwestern Mediterranean Sea (Dyfamed site). Deep Sea Research Part II: Topical Studies in Oceanography, 49 (11), 2031-2047.

[33] Cantoni C., Luchetta A., Celio M., Cozzi S., Raicich F., and Catalano G., 2012. Carbonate system variability in the Gulf of Trieste (North Adriatic Sea). Estuarine. Coastal and Shelf Science, 115, 51-62.

[34] La Ferla R., Azzaro M., Civitarese G., and Ribera d'Alcalà M., 2003. Distribution patterns of carbon oxidation in the eastern Mediterranean Sea: Evidence of changes in the remineralization processes. Journal of Geophysical Research, 108 (C9), 8111, doi:10.1029/2002JC001602, C9.

[35] Santana-Casiano J.M., Gonzalez-Davila M. and Laglera L.M., 2002. The carbon dioxide system in the Strait of Gibraltar. Deep-Sea Research, II. Topical studies in oceanography, 49, 4145-4161.

[36] Aït-Ameur N. and Goyet C., 2006. Distribution and transport of natural and anthropogenic CO2 in the Gulf of Cadiz. Deep Sea Research Part II: Topical Studies in Oceanography, 53 (11-13), 1329-1343.

[37] Huertas I.E., Ríos A.F., García-Lafuente J., Makaoui A., Rodríguez-Gálvez S., Sánchez-Román A., Orbi A., Ruíz J., and Pérez F.F., 2009. Anthropogenic and natural CO2 exchange through the Strait of Gibraltar. Biogeosciences Discussion, 6, 1021-1067. 